\title{
The Swastika and the Maple Leaf: National-Socialism and Anti-Semitism in Canada
}

Joshua Loewen

Anti-Semitism in Canada in the 1930's and before is widely documented, but the influence of National-Socialism in Canada is less well-known. In fact, National-Socialism had a number of adherents in Canada and was an important influence on Canadian politicians and organizations who defined themselves by their support for or opposition to National-Socialism, especially in terms of their views on anti-Semitic ideas. The racist tenets of anti-Semitism in Canada were closely connected to and defined by the National-Socialist ideology that spread to Canada from Nazi Germany. The two intermingled in politics and in grassroots organizations, as well as in informal racism throughout Canada.

Anti-Semitism in Canada in the 1930's and before is widely documented, but the influence of National-Socialism in Canada is less well-known. In fact, National-Socialism had a number of adherents in Canada and was an important influence on Canadian politicians and organizations who defined themselves by their support for or opposition to National-Socialism, especially in terms of their views on anti-Semitic ideas. The racist tenets of anti-Semitism in Canada were closely connected to and defined by the National-Socialist ideology that spread to Canada from Nazi Germany. The two intermingled in politics and in grassroots organizations, as well as in informal racism throughout Canada.

Although it existed in Canada long before the 1930's, in that decade anti-Semitism in Canada became defined by the ideology and influence of the National-Socialist movement. In "Fascism in Canada", Stephen R. Barret argues that it was "as Hitler... began to make an impact upon the world scene, [that] anti-Semitism sprang into the open". ${ }^{1}$ Irving Abella and Harold Troper go even further, arguing that "power did not soften anti-Semitism, it legitimized it; power shifted anti-Semitism from speeches to policy, then from policy to law". ' Canadian anti-Semitism became organized and defined by its relationship to the Third Reich in Germany. The influence of the Third Reich on anti-Semitism in Canada can be separated two distinct spheres: the area of public opinion and the political arena, particularly the areas of diplomatic relations and

\footnotetext{
${ }^{1}$ Stanley R. Barret, "Fascism in Canada", Contemporary Crises 8, no. 4 (October 1984), 351

${ }^{2}$ Irving Abella and Harold Troper, None is too Many (Ontario: Lester \& Orpen Dennys Limited, 1982), 3
} 
immigration laws. Among the public, there were Nazi organizations imported from Germany that organized anti-Semitism around Canadian issues. Even organizations that were not officially affiliated with the Nazis - such as parts of the Christian church, and the Ku Klux Klan espoused Nazi ideology concerning anti-Semitism. Nazism also influenced politicians like Mackenzie King, and there were many parallels between Canadian anti-Semitic political rhetoric and Nazi ideas. It can be asserted that, after 1933, anti-Semitism in Canada became defined by the influence, propaganda, and political movements of National-Socialism in Germany.

Public anti-Semitism in Canada was organized and influenced by National-Socialist parties directly linked with the Third Reich. The National-Socialist parties imported from Germany included the Auswartiges Amt, the traditional Foreign Office of Germany, which distributed propaganda, and the Deutscher Bund Canada, which concerned itself mostly with spreading Nazi rhetoric among German farmers and German clubs. In western Canada, German National-Socialism found its main public adherents in Canada among the nation's ethnic Germans. From 1927 to 1931, 77,963 German arrived in Canada; of these immigrants, only $19,361(24.7 \%)$ were actually from Germany and the others mainly from various countries in Eastern Europe. ${ }^{3}$ By 1931, there were roughly half a million ethnic Germans in Canada. ${ }^{4}$ After 1933, many of these German immigrants formed and filled the National-Socialist parties in Canada. ${ }^{5}$ According to Joseph Wagner, in Brothers Beyond the Sea: National- Socialism in Canada, the most common motive for joining National-Socialist groups was a sense of pan-national German community (in German, the Volk or Volksgemeinschaft). ${ }^{6}$ The fact that these ethnic Germans were from separate nations, not from the "Fatherland", actually caused the growth of the idea of Volk to become increasingly prominent among Germans in Canada. The idea of the Volk was a combination of mysticism and pseudo-scientific racism, defining the people that belonged to it by physical attributes, as well as spiritual qualities, against the archetypal "other": the Jew. ' Groups like the Deutscher Bund Canada, meant "to defend German culture and to uphold the rights of the German minority against the majority group", distributed many types of propaganda, most importantly anti-Semitic material, in addition to organizing activities and facilitating anti-Semitic beliefs. ${ }^{9}$ The anti-Semitic propaganda, activities and culture of these Nazi organizations both spread anti-Semitism and defined the anti-Semitism of their members.

\footnotetext{
${ }^{3}$ Wagner, Brothers Beyond the Sea, 12

${ }^{4}$ Ibid., 8

${ }^{5}$ Ibid., 20-21

${ }^{6}$ Ibid., 28

${ }^{7}$ Wagner, Brothers Beyond the Sea, 15

${ }^{8}$ Ibid., 16

${ }^{9}$ Ibid., $52-60$
} 
The economic hardships of the Great Depression made both anti-Semitism and the organizations that spread it more appealing to disenfranchised and suffering Germans. Amidst the combined failures of economy and climate during the Great Depression, National-Socialist groups blamed Jews, granting a scapegoat to those affected. Nazi propaganda in Canada depicted Jews as divorced from the Volk, from humanity, and especially from nature, in addition to controlling the system of "grasping, heartless capitalism". ${ }^{10}$ The Nazi organizations argued that the droughts in Canada were a failure of nature caused by unnatural Jewry or Jewish mysticism (note this combination of mysticism and race) and also that the failure of the capitalist economy was a result of Jewish control. ${ }^{11}$ Membership in most Nazi groups peaked during the worst years of the Depression. $^{12}$ In this period, the Bund had roughly 2000 members; the pro-Nazi Arbeitsgemeinschaften and provincial Tage groups had combined membership around 4000; and pro-Nazi weeklies were distributed to at least 70,000 German-Canadians every week. ${ }^{13}$ Most of these people were poor or unemployed, suffering under the Depression. ${ }^{14}$ The Depression created a tense atmosphere in Canada, and National-Socialism rallied the Germans in Canada by consoling them with a Jewish scapegoat that they could take out their anger on. The Great Depression was thus a Canadian issue used by German Nazi organizations to spread and control Canadian anti-Semitism.

Canadian organizations that were not affiliated with the Third Reich were also influenced by Nazism and anti-Semitism coming from Germany. Parts of the Christian church, for example, mingled with National-Socialism and anti-Semitism, and furthered the persecution of Jews. In "The Contours of Canadian Jewish Life", Randall F. Schnoor comments that during the 1930's the sense of security that Jews felt in Canada was plummeting, and there was a growing feeling of "outsiderness". ${ }^{15}$ A great deal of this opposition stemmed from Christians within Canada, who saw Jews as impure, and as opponents of their religion. ${ }^{16}$ This connects with portrayals of Hitler as a suffering, Christ-like figure in Nazi propaganda posters, pamphlets, and films - such as Unser Fuhrer - which were distributed in Canada. ${ }^{17}$ In fact, Hitler himself often acted as a Christian: upon being asked how he found his inspiration, he pulled out a Bible, and responded "from God's Word". 18 Adrian Arcand, the fascist leader in Quebec, also portrayed Hitler as the

\footnotetext{
${ }^{10}$ Ibid., 30

11 Ibid.

12 Ibid., 68

${ }^{13}$ Wagner, Brothers Beyond the Sea, 68; 91; 95; 114

14 Ibid., 70

${ }^{15}$ Randall F. Schnoor, "The Contours of Canadian Jewish Life”, Contemporary Jewry no. 3 (2011), 181-182

${ }^{16}$ Abella Troper, None is too Many, 51

${ }^{17}$ Wagner, Brothers Beyond the Sea, 44-51; 61

${ }^{18}$ Ibid., 111
} 
champion of Christianity. ${ }^{19}$ A pastor named Dr. Mieneke declared to his congregation that "Christ himself was a Hitlerite. The Christian Cross and the swastika belong together". ${ }^{20}$ Judaism was often associated with all Jews (practicing or not) and was seen as a dangerous, unspiritual, and false religion. ${ }^{21}$ These messages reached out to the average Christian living in Canada, combining Christianity and National-Socialism to propagate anti-Semitism.

Other organizations also propagated similar ideas, especially in Toronto, where Jews were subject to anti-Semitism that was National-Socialist in character. In Toronto, Swastika Clubs were formed as early as 1933, and their members organized marches, displayed swastikas on armbands and flags, shouted "Heil Hitler" in public, and participated in anti-Semitic activities (including beatings). 22 Signs such as "Patronage exclusively Gentile" and "No Jews or Dogs Allowed" were common fixtures of storefronts in Toronto and many other Canadian cities, closely mimicking those to be seen in the Third Reich. ${ }^{23} \mathrm{Ku}$ Klux Klan organizations were also becoming increasingly popular by 1937, violently attacking Jews and other non-whites, often while bearing the sign of the swastika. ${ }^{24}$ This was the period in which the Ku Klux Klan and the swastika first became associated, mingling anti-Semitism and Nazism. National-Socialism as a political ideology and as a social movement both created new anti-Semitic organizations and exacerbated the anti-Semitism that already existed in Canada.

In Quebec, Nazi influence also existed, but it was often a more subtle stimulus to existing anti-Semitic and right-wing leaders. Andre Arcand of the Parti National Social Christian and Lionel Groulx, an influential Roman Catholic Priest and historian in Quebec, both adopted Nazi ideas - such as the "Fuhrer principle" - as part of their own anti-Semitic and political beliefs. Lionel Groulx, a Roman Catholic Priest and historian in Quebec, wrote "Lucky [the] nations which have managed to find a dictator". ${ }^{26}$ The fascist leader Andre Laurendeau epressed a similar sentiment, describing Quebec's search for "the nation's savior... this tall figure, this man who will embody our hope, expressing them heroically and definitively". ${ }^{27}$ Now, this is eerily

\footnotetext{
${ }^{19}$ Barret, "Fascism in Canada", 351

${ }^{20}$ The Toronto Daily Star, 5 April 1933: 1, quoted in Levitt and Shaffir , "the Swastika as Dramatic Symbol", 83

${ }^{21}$ Alan Mendelson, Exiles from Nowhere: The Jews and the Canadian elite (Manitoba: Robin Press Studio, 2008), 208

${ }^{22}$ Levitt and Shafir, "The Swastika as Dramatic Symbol", 81-83

${ }^{23}$ Ibid., 80

${ }^{24}$ Barret, "Fascism in Canada", 355

${ }^{25}$ Barret, "Fascism in Canada", 350-351; Cyril Levitt and William Shafir, "The Swastika as Dramatic Symbol: A Case Study of Ethnic Violence in Canada", in The Jews in Canada, ed. Robert J. Brym, William Shaffir, Morton Weinfeld (Ontario: Oxford University Press, 2010), 81-83

${ }^{26}$ Lionel Groulx, "Pour Qu'on Vive", Action Nationale (January, 1934), quoted in Esther Delisle, The Traitor and the Jew: Anti-Semitism and extreme right-wing nationalism in Quebec from 1929 to 1939, trans. Madeleine Hebert, with Claire Rothman and Kathe Roth (Montreal: R. Davies Publishing, 1993), 182

${ }^{27}$ Andre Laurendeau, Qui Sauvera Quebec, quoted in Delisle, The Traitor and the Jew, 183
} 
similar to how German propaganda in Canada described der Fuhrer, especially in films such as Triumph de Willens and Unser Fuhrer, which were distributed widely across Canada by the Deutscher Bund and Auswartiges Amt, including in Quebec. ${ }^{28}$ The people and organizations that received these ideas then organized anti-Semitic rhetoric and activities around these Nazi principles, built upon a foundation of extremist right-wing parties and popular anti-Semitism that already existed within Quebec.

Nazism and anti-Semitism mingled with popular politics in Quebec. In a 1906 speech, Henri Bourassa - a prominent Quebec politician - described Jews as "vampires" on the community, which is representative of his own anti-Semitic beliefs. ${ }^{29}$ On campaign, the fascist Andre Laurendeau promoted the campaign of Bourassa and introduced him to wildly enthusiastic audiences, a significant union of fascism and anti-Semitism in Quebec politics. ${ }^{30}$ Bourassa and Laurendeau were not National-Socialist in allegiance and did not pay any homage to Hitler or the Third Reich, but they did imitate many Nazi ideals and statements. Andre Arcand, however, went much further. He was an outspoken admirer of Adolf Hitler, and led the Parti National Social Christian in Quebec (this party was also another example of National-Socialism merging with Christianity). Arcand's party is described by Stanley R. Barret as "the most virulent fascist movement in the country", trumpeting Hitler National-Socialism, and the destruction of world Jewry as the solutions to the world's problems. ${ }^{31}$ In fact, Jews were demonized and scapegoated in all of these movements. ${ }^{32}$ Leaders such as Pelletier of Le Devoir, Peter Bercovitch, and others, also propagated rabid anti-Semitism and extreme nationalism that reflected National-Socialist ideology. ${ }^{33}$ Once again, National-Socialism influenced and justified anti-Semitism in a Canadian - specifically Quebec - context.

The organization and spread of anti-Semitism in Canada had tragic consequences. After Adolf Hitler became Chancellor of Germany in 1933, there was an ever-increasing tide of Jews looking to emigrate away from Europe, first from Germany, and then from nearly every nation on the continent. ${ }^{34}$ Sadly, Canada shut its doors to the Jews. The German Third Reich had influenced this attitude towards Jews in two ways: by creating the situation of a Jewish exodus from Europe, and by setting a precedent for its handling. On September 15, 1935, the Nuremberg Laws were passed in Germany, disenfranchising Jews and revoking their citizenship, and German Jews

\footnotetext{
${ }^{28}$ Wagner, Brothers Beyond the Sea, 60-61

${ }^{29}$ Mendelson, Exiles from Nowhere, 61

${ }^{30}$ Ibid., 64

${ }^{31}$ Barret, "Fascism in Canada", 351

${ }^{32}$ Ibid.

${ }^{33}$ Delisle, The Traitor and the Jew, 166-169

${ }^{34}$ Ibid., 3-5
} 
sought new homes elsewhere. ${ }^{35}$ Irving Abella and Harold Troper argue that this set off a wave of protests, particularly in Eastern Europe, demanding to "follow the German precedent" and remove Jews from their countries entirely. ${ }^{36}$ In None is Too Many, they also extend this to Mackenzie King, and state that "It was Mackenzie King... and his cabinet ministers who, in the final analysis, were responsible for keeping Jews out of Canada", both because of their personal anti-Semitism and popular anti-Semitism in Canada (particularly the Quebec political movements mentioned earlier) ${ }^{37}$. The anti-Semitism of the Third Reich lent precedence to anti-Semitism in Canada's government.

Nazism had a particular influence on the anti-Semitism of Prime Minister Mackenzie King, in office from 1935 to 1948, which tied in with the exclusion of Jews from Canada. He was described by William Grant as "selfishness disguised by a thick smear of sentimentalism... [willing to] sacrifice anyone or anything to his ambition, and then sob about it". ${ }^{38}$ It is a particularly interesting quote in that this attitude seems to have been predominant in Canadian policy towards both the Reich and the Jews. When King met Hitler personally, in Berlin on June 19, 1937, he recorded in his diary that he was deeply impressed with the practical success of Hitler at restoring Germany's economy (he had toured the city earlier) and what he saw as Hitler's benevolent personality. ${ }^{39}$ Most importantly, however, King saw Hitler's policies as justifying his own anti-Semitism. King himself held a number of anti-Semitic beliefs, referring to Jews in his diary as "detestable" and as "blood-suckers", and later that he even sympathized with Hitler's racial policies towards Jews. ${ }^{41}$ King's views on Nazi Germany and on Jews affected Canadian domestic policy, particularly the Canadian immigration laws that would hold the power of life and death over many European Jews: of more than 800,000 Jews that attempted to gain entrance into Canada from 1933 to 1939 , only 4000 were allowed to enter. ${ }^{42}$ National-Socialism influenced the personal anti-Semitism of the Canadian Prime-Minister.

It is worth mentioning that there were Canadian who embraced anti-Semitism but rejected Nazism, but even they were influenced by Nazism in the sense that they felt the need for pretense and duplicity in their anti-Semitic activities to avoid being labelled as Nazis. In "Anti-Semitism:

\footnotetext{
${ }^{35}$ Abella and Troper, None is too Many, 4

${ }^{36}$ Irivng Abella and Harold Troper, “'The Line Must be Drawn Somewhere': Canada and Jewish Refugees, 1933-9”, Canadian Historical Review 60, (June 1979), 179

${ }^{37}$ Abella and Troper, None is too Many, 9

${ }^{38}$ R. MacGregor Dawson, William Lyon Mackenzie King: A Political Autobiography 1874-1923 (Ontario: University of Toronto Press), quoted in Mendelson, Exiles from Nowhere, 69

${ }^{39}$ Mendelson, Exiles from Nowhere, 73-75

${ }^{40}$ Mackenzie King, Diary, 24 September 1898, quoted in Mendelson, Exiles from Nowhere: The Jews and the Canadian elite (Manitoba: Robin Press Studio, 2008), 65

${ }^{41}$ Mendelson, Exiles from Nowhere, 75

${ }^{42}$ Irving Abella, “Canada and the Jewish Refugee Crisis 1933-1939," Michael 9 (1986): 10
} 
The Uneasy Calm", Arnold Ages describes the screening of Jewish university candidates, their exclusion on the basis of "dexterity requirements", and open abuse by anti-Semitic professors, yet he comments that none of these universities formally adopted anti-Semitic rules. ${ }^{43}$ Goldwin Smith, a writer, professor, and influential anti-Semite of Ontario, extolled the "Brotherhood of Man" while simultaneously publishing papers such as "The Jewish Question" and promoting the extinction of Judaism and the removal of Jews from Western Society. ${ }^{44}$ Frederick Charles Blair, responsible for many duties involving immigration during the 1930's, insisted that by keeping Jews out of Canada - regardless of news of pogroms and persecution of Jews in Europe - he was simply being "realistic about Canada's immigration needs". ${ }^{45}$ This sense of the need for pretense and duplicity was a key factor of Canadian anti-Semitism, which certainly separated it from the brand of anti-Semitism practiced in the Third Reich. The need to hide or cover anti-Semitism can be taken as a reaction to and influence of Nazism on Canadian anti-Semitism. Cyril Levitt and William Shafir comment that citizens of Toronto would often rail against Hitler's overtly racist policies, while at the same time practicing individual anti-Semitism, which is a good example of this contradictory behavior. ${ }^{46}$ That the average Canadian did not want to be seen as a Nazi, but still participated in anti-Semitic behavior under other names, was itself a facet of the influence of National-Socialism on Canadian anti-Semitism.

National-Socialism came to organize and define anti-Semitism in Canada. After the rise of the Third Reich, parties and groups flying the Swastika banner became increasingly common. National-Socialism in Germany gave license and precedence to organized anti-Semitism in Canada. In the public sphere, National-Socialist parties and even non-affiliated groups propagated anti-Semitic rhetoric and activities. Politically, powerful figures like Mackenzie King seemed to sympathize with Hitler, and continued to practice anti-Semitism. Jewish immigration was blocked, Jews were persecuted, and the swastika flew on flags and was worn on armbands throughout the nation. Anti-Semitism of all kinds appropriated Nazi ideas and imagery, lending a face and organization to Canadian anti-Semitism. Once a latent and disorganized sentiment, anti-Semitism in Canada was organized and defined by German National-Socialism, whether in agreement or in opposition.

\footnotetext{
${ }^{43}$ Arnold Ages, "Anti-Semitism: the Uneasy Calm", in The Canadian Jewish Mosaic, ed. Morton Weinfield, Irwin Cotler and William Shafir (Ontario: John Wiley \& Sons, 1981), 387

${ }^{44}$ Mendelson, Exiles from Nowhere, 49; 53-54

${ }^{45}$ Abella and Troper, None is too Many, 7-8

${ }^{46}$ Levitt and Shafir, "The Swastika as Dramatic Symbol", 78-80
} 


\section{Bibliography}

Abella, Irving and Harold Troper. None is too Many. Ontario: Lester \& Orpen Dennys Ltd, 1982.

Abella, Irving and Harold Troper. "'The Line Must be Drawn Somewhere': Canada and Jewish Refugees, 1933-9." Canadian Historical Review 60, 1979: 178-209.

Ages, Arnold. “Anti-Semitism: the Uneasy Calm", in The Canadian Jewish Mosaic. Edited by Morton Weinfield, Irwin Cotler and William Shafir. Ontario: John Wiley \& Sons, 1981.

Barret, Stanley R. "Fascism in Canada." Contemporary Crises 8, no. 4, 1984: 345-377.

Belkin, Simon. Through Narrow Gates: a review of Jewish immigration, colonization and immigrant aid work in Canada, 1840-1940. Montreal: Eagle Publishing, 1966.

Delisle, Esther. The Traitor and the Jew: Anti-Semitism and extreme right-wing nationalism in Quebec from 1929 to 1939. Translated by Madeleine Hebert, with Claire Rothman and Kathe Roth. Montreal: R. Davies Publishing, 1993.

Levitt, Cyril and William Shafir. "The Swastika as Dramatic Symbol: A case study of ethnic violence in Canada", in the Jews in Canada. Edited by Robert J. Brym, William Shaffir and Morton Weinfeld. Ontario: Oxford University Press, 2010.

Mendelson, Alan. Exiles from Nowhere: The Jews and the Canadian elite. Manitoba: Robin Press Studio, 2008.

Schnoor, Randall F. “The Contours of Canadian Jewish Life.” Contemporary Jewry, no. 3. (2011): 179-197.

Wagner, Jonathon F. Brothers Beyond the Sea: National-Socialism in Canada. Ontario: Wilfrid Laurier University Press, 1981. 